\title{
SENSORY PROPERTIES OF CUSTARD SOY-BASED DESSERTS PREDICTED BY RAPID INSTRUMENTAL MEASUREMENTS
}

\author{
JORDANA C. SPADA* \\ LIGIA DAMASCENO FERREIRA MARCZAK** \\ ISABEL CRISTINA TESSARO** \\ SIMONE HICKMANN FLÔRES ${ }^{* * *}$ \\ NILO SÉRGIO MEDEIROS CARDOZO**
}

\begin{abstract}
The aim of this work was to assess to what extent rheological properties can explain the sensory texture in soy based desserts containing different amounts of water soluble soy extract, modified starch and guava pulp, as well as to correlate the sensory and instrumental color. Seventeen creamy soy based desserts were studied. Sensory ranking tests were performed by Quantitative Descriptive Analysis (QDA) and affective sensory tests. Correlations between sensory and instrumental data were determined using Pearson's correlation coefficient. Results showed a moderate positive correlation between sensory color and $a^{*}$, and significant negative correlations with $L^{*}$ and $h_{a b}$. Loss modulus at 1 and 10 rad $\mathrm{s}^{-1}$ and the parameters $n$ " were the rheological parameters better correlated with the sensory attributes related to consistency and creaminess. Moreover, the results found in the affective tests can be explained by those verified in QDA.
\end{abstract}

KEY-WORDS: QDA, RHEOLOGY, COLOR, SOYFOODS.

"Ph.D student in the area of heat and mass transfer, Chemical Engineering Department, Universidade Federal do Rio Grande do Sul (UFRGS), Porto Alegre, RS (e-mail: jcorralospada@yahoo.com.br).

**Professor, Chemical Engineering Department, UFRGS, Porto Alegre, RS (e-mail: isabel@enq.ufrgs.br; ligia@ eng.ufrgs.br; nilo@enq.ufrgs.br).

${ }^{* * *}$ Professor, Food Science and Technology Institute, UFRGS, Porto Alegre, RS (e-mail: simone.flores@ufrgs.br) 


\section{INTRODUCTION}

Sensory evaluation can be seen as a link between research and development, with focus on technical aspects of food, consumer and marketing research, and consumers' behavior and psychology (Dijksterhuis, 1997). It measures the reaction to stimuli resulting from the use or consumption of a product through analytical and/or affective tests. Traditionally, analytical tests (discriminative and descriptive) are performed with trained panels whereas affective tests are run with consumers (Stone and Sidel, 1985).

Proper evaluation of sensory characteristics takes time and is therefore costly. To save time and money, instrumental methods can be useful for replace the sensory tests. It is generally accepted that instrumental methods (such as rheology) could be useful to broaden the knowledge of the reasons for which different products have different sensory characteristics (Wortel, Verboom, Wiechiers, Taelman, \& Leonard, 2005).

Some authors investigated the relationship between instrumental and sensory attributes of food systems such as vanilla desserts, including dairy and non-dairy samples (Arltoft, Madsen, \& Ipsen, 2008; De Wijk, Prinz, \& Janssen, 2006; de Wijk, Van Gemert, Terpstra, \& Wilkinson, 2003; Depypere, Verbeken, Thas, \& Dewettinck, 2003; Lethuaut, Brossard, Rousseau, Bousseau, \& Genot, 2003; Tárrega \& Costell, 2007; Wendin \& Hall, 2001), and semi-solid milk desserts (Arltoft, Madsen and Ipsen,2008). Although all these authors found significant correlations between sensory and instrumental parameters, they did not studied the components concentration.

To the best of our knowledge, there is no prior work addressing the possible relationships between values of physical properties and sensory characteristics in soy based desserts. In this context, the goal of the present work was to study the correlation between instrumental and sensory measurements in custard-like soy based desserts.

\section{MATERIAL AND METHODS}

\subsection{MATERIALS, SAMPLE PREPARATION AND RHEOLOGICAL DATA}

The samples used to evaluate the influence of the composition on the sensory and color characteristics were prepared using the same materials and preparation procedures as described in the preceding paper (Spada, Marczak, Tessaro, Flôres, \& Cardozo, 2014), as well as the rheological data. For sake of conciseness, the coded and decoded values of the three factors (water soluble soy extract, modified starch and guava pulp contents) corresponding to each of these formulations are presented in Table 1, together with the results for the sensory attributes. In Quantitative Descriptive Analysis were used different commercial materials to train the sensory panel as dulce de leche (Vonpar Alimentos, Viamão, Brazil), creamy condensed milk (Nestlé, Germany), semi-skimmed milk (Elegê, Brazil) and red dye (Mix Indústria de Produtos Alimentícios, São Bernardo do Campo, Brazil). 
TABLE 1 - SENSORY ATTRIBUTES OF THE SOY-BASED DESSERTS IN QDA TEST

\begin{tabular}{|c|c|c|c|c|c|c|c|c|c|c|c|}
\hline \multirow{2}{*}{ Assays } & \multicolumn{3}{|c|}{ Coded levels } & \multicolumn{3}{|c|}{ Original levels } & \multicolumn{5}{|c|}{ Sensory attributes ${ }^{*}$} \\
\hline & $x_{1}$ & $x_{2}$ & $x_{3}$ & $\begin{array}{c}\text { Soy } \\
\text { extract } \\
(\%)\end{array}$ & $\begin{array}{c}\text { Starch } \\
(\%)\end{array}$ & $\begin{array}{c}\text { Guava } \\
\text { pulp } \\
(\%)\end{array}$ & $\begin{array}{l}\text { Pink } \\
\text { color }\end{array}$ & $\begin{array}{l}\text { Consis- } \\
\text { tency }\end{array}$ & $\begin{array}{l}\text { Soy } \\
\text { flavor }\end{array}$ & $\begin{array}{l}\text { Guava } \\
\text { flavor }\end{array}$ & $\begin{array}{c}\text { Creami- } \\
\text { ness }\end{array}$ \\
\hline 1 & -1 & -1 & -1 & 3.5 & 2.9 & 9.5 & $2.99 \mathrm{bc}$ & $4.28 \mathrm{bc}$ & $0.46^{c}$ & $5.68^{\mathrm{bc}}$ & $5.90 \mathrm{bc}$ \\
\hline 2 & 1 & -1 & -1 & 6.5 & 2.9 & 9.5 & $1.65^{\mathrm{cd}}$ & $4.96^{b}$ & $0.53^{c}$ & $3.81^{\mathrm{cd}}$ & $5.46^{c}$ \\
\hline 3 & -1 & 1 & -1 & 3.5 & 3.7 & 9.5 & $2.55^{c d}$ & $6.21^{\mathrm{ab}}$ & $0.53^{c}$ & $5.51^{\mathrm{bc}}$ & $6.49^{b}$ \\
\hline 4 & 1 & 1 & -1 & 6.5 & 3.7 & 9.5 & $0.63^{e}$ & $7.54^{a}$ & $0.85^{c}$ & $4.81^{b c}$ & $7.65^{a}$ \\
\hline 5 & -1 & -1 & 1 & 3.5 & 2.9 & 16.5 & $2.59 \mathrm{~cd}$ & $5.28^{b}$ & $0.40^{c}$ & $7.33^{a}$ & $5.34^{c}$ \\
\hline 6 & 1 & -1 & 1 & 6.5 & 2.9 & 16.5 & $1.05^{e}$ & $6.98^{a}$ & $0.94^{c}$ & $5.51^{\mathrm{bc}}$ & $6.33^{b}$ \\
\hline 7 & -1 & 1 & 1 & 3.5 & 3.7 & 16.5 & $4.10^{b c}$ & $5.53^{b}$ & $0.58^{c}$ & $6.16^{\mathrm{ab}}$ & $7.08^{a}$ \\
\hline 8 & 1 & 1 & 1 & 6.5 & 3.7 & 16.5 & $2.63^{c d}$ & $6.39 \mathrm{ab}$ & $\underset{b c}{1.36}$ & $6.05^{\mathrm{ab}}$ & $6.90^{a}$ \\
\hline 9 & -1.68 & 0 & 0 & 2.5 & 3.3 & 13.0 & 5.49 a & $3.24^{c}$ & $0.62^{c}$ & $6.54^{\mathrm{ab}}$ & $3.97^{d}$ \\
\hline 10 & 1.68 & 0 & 0 & 7.5 & 3.3 & 13.0 & 1.36 de & $6.51^{\mathrm{ab}}$ & $3.58^{a}$ & $3.05^{\mathrm{d}}$ & $7.24^{\mathrm{a}}$ \\
\hline 11 & 0 & -1.68 & 0 & 5.0 & 2.6 & 13.0 & $1.98^{d}$ & $7.09^{a}$ & $0.76^{c}$ & $6.98^{a}$ & $7.34^{\mathrm{a}}$ \\
\hline 12 & 0 & 1.68 & 0 & 5.0 & 4.0 & 13.0 & $2.15^{c d}$ & $5.33^{b}$ & $0.69^{c}$ & $6.58^{\mathrm{ab}}$ & $5.84^{b c}$ \\
\hline 13 & 0 & 0 & -1.68 & 5.0 & 3.3 & 7.0 & 1.45 de & $4.98^{b}$ & $0.50^{\circ}$ & $1.99^{d}$ & $5.49^{\circ}$ \\
\hline 14 & 0 & 0 & 1.68 & 5.0 & 3.3 & 19.0 & $4.20^{\mathrm{b}}$ & $5.06^{b}$ & $0.45^{c}$ & $6.84^{\mathrm{ab}}$ & $5.34^{\circ}$ \\
\hline 15 & 0 & 0 & 0 & 5.0 & 3.3 & 13.0 & $2.74^{\mathrm{c}}$ & $6.05^{b}$ & $1.51^{\mathrm{b}}$ & $6.28^{\mathrm{ab}}$ & $6.44^{b c}$ \\
\hline 16 & 0 & 0 & 0 & 5.0 & 3.3 & 13.0 & $2.13^{c d}$ & $5.71^{\mathrm{b}}$ & $1.80^{b}$ & $5.88^{\mathrm{bc}}$ & $6.81^{\mathrm{ab}}$ \\
\hline 17 & 0 & 0 & 0 & 5.0 & 3.3 & 13.0 & $2.86^{\mathrm{c}}$ & $5.11^{\mathrm{b}}$ & $\begin{array}{c}2.06 \\
a b\end{array}$ & $5.34^{\mathrm{bc}}$ & $5.83^{b c}$ \\
\hline
\end{tabular}

"Data expressed by mean $(n=10)$. Means within column followed by different superscripts, are significantly different at $p<$ 0.05 using Tukey test. 


\subsection{COLOR MEASUREMENT}

Color was measured in a colorimeter (Konica Minolta Sensing Inc., CR 400, Japan) using optical glass cells $2 \mathrm{~cm}$ high and $6 \mathrm{~cm}$ diameter. The color reader was calibrated using a calibration dish CR A43. Results were expressed using the CIE $L^{*} a^{*} b^{*}$ color space with reference to illuminant D65 and a visual angle of $10^{\circ}$. From $a$ and $b$, the psychological parameters chroma $C^{*}$ and hue $\left(h_{a b}\right)$ are calculated.

\subsection{SENSORY EVALUATION}

Quantitative Descriptive Analysis was conducted as reported in Spada et al. (2014). Affective sensory tests were also conducted to describe the degree of liking with relation to each individual attribute (color, appearance, consistency, odor, flavor, and creaminess) and the overall acceptability. In this case, the sensory panel consisted of habitual consumers of desserts who were asked to classify the samples by assigning a liking score on a 9-point hedonic scale from $1=$ 'dislike extremely' to $9=$ 'like extremely'. The dessert samples were presented randomly for each panelist.

The tests were conducted in individual booths at Sensory Analysis Laboratory of Department of Food Science and Technology. All panelists received and signed an informed consent approved by the Ethics Committee of UFRGS (protocol number 108.982).

\subsection{STATISTICAL ANALYSIS}

For the statistical analysis of the instrumental color and sensory data, analysis of variance (ANOVA) and Tukey test were performed, using the software Statistica for Windows, version 12 (StatSoft, Tulsa, OK, USA). A P-value bellow 0.05 was considered significant. Correlations between instrumental and sensory parameters were verified using Pearson's correlation matrix.

\section{RESULTS AND DISCUSSION}

\subsection{SENSORY ANALYSIS}

Table 1 shows the mean sensory scores for the samples evaluated in QDA. Results showed significant differences $(p \leq 0.05)$ in all attributes of samples. Sample 9 was ranked as with more pink color and no significant differences were found between samples 4, 6, 10 and 13 which were ranked as less pink color. Regarding texture ranking, sample 9 was perceived as the sample with the lowest consistency and creaminess and no significant differences were found between samples 4, 6, 8, 10 and 11 which were perceived as more consistent and creamier. For flavor, the sample 10 presented more soy flavor and less guava flavor, since it contains more water soluble soy extract in its formulation.

Table 2 presents the significant effects on the sensory attributes. Soy flavor was affected by all linear effects. As expected the water soluble soy extract content increased the soy flavor value, while guava pulp and modified starch decreased this value. Guava flavor and pink color were positively affected by guava pulp content and negatively by soy content. As the starch and soy extract are considered promoters of texture in foods, the effects of these variables on the creaminess and consistency attributes were significant.

The results found in the affective sensory tests (Table 3 ) are in agreement with the results found in QDA, since that the samples with pink color and more intense guava flavor showed higher mean scores for color, appearance, flavor and acceptance. Only samples 1, 7, 8, 9, 10 and 13 were chosen affective sensory tests because they constitute the smaller subset of the studied samples which are representative of all differences and similarities among samples found in the QDA. Regarding the creaminess and consistency, the mean scores were significantly smaller for samples 9 and 10 in the affective tests. In QDA, dessert 9 was ranked as less consistent and creamy, unlike 
the sample 10 that presented higher scores. Although the sample 10 is statistically equal to samples 7 and 8, considering consistency and creaminess in QDA, it was considered as gummy by some tasters, what may have been the cause of its lower approval rate $(72 \%)$ in affective tests. Samples 7 and 8 that presented the higher approval rates (higher than $80 \%$ ) for consistency and creaminess, received high scores in QDA. However, some consumers preferred samples less consistent.

\subsection{INSTRUMENTAL COLOR}

Table 4 presents the effects that were significant $(p<0.05)$ on the instrumental color parameters. Higher concentrations of guava pulp $\left(x_{3}\right)$ reduced lightness in the desserts, while soy protein $\left(x_{1}\right)$ had the tendency to increase the $L^{*}$ coordinate of the assays. Moreover, one interaction $\left(x_{2} \cdot x_{3} \square\right.$ starch/guava pulp interaction) was significant.

The assay number $13(0,0,-1.68)$ with less guava pulp presented the lowest red coordinate value $\left(a^{*}=3.33\right)$. As expected, the higher the guava pulp content $\left(x_{3}\right)$ in the desserts, the more reddish they became, as observed by an increase of the $a^{*}$ coordinate, while soy protein $\left(x_{1}\right)$ had the tendency to decrease the $a^{*}$ coordinate of the assays, However, the significance of the linear effects $\left(x_{1}\right.$ and $\left.x_{3}\right)$ together with one quadratic ( $x_{1}^{2} \square$ soy extract) and one interaction ( $x_{2} \cdot x_{3} \square \operatorname{starch} /$ guava pulp interaction) shows that the dependence of the $a^{*}$ parameter on the composition in the formulations is quite complex.

A lower hue angle represents a lower yellow character in the assays and greater redness intensity. Table 4 shows that guava pulp decreased the hue angle value, i.e., increased the redness of assays, while the soy extract increase this characteristic.

Table 4 shows that soy extract $\left(x_{1}\right)$ and guava pulp $\left(x_{3}\right)$ increased the $b^{*}$ coordinate values (yellowness) and chroma of assays. The higher the chroma value, the higher the color intensity of hue perceived by human vision.

Color variations among samples can be explained by the color difference of the formulation components (total color difference between soy extract and guava pulp is 61.28), since that the soy extract presents yellow tonality (high $h_{a b}$ value) and high lightness $\left(L^{*}=106.31 ; a^{*}=-1.59 ; b^{*}=21.03\right.$; $\left.h_{a b}=94.32\right)$, unlike

TABLE 2 -SIGNIFICANT EFFECTS ON THE INSTRUMENTAL COLOR PARAMETERS

\begin{tabular}{|c|c|c|c|c|c|}
\hline $\begin{array}{c}\text { Instrumental } \\
\text { color } \\
\text { parameters }\end{array}$ & $\begin{array}{c}L^{*} \\
\text { (brightness) }\end{array}$ & $\begin{array}{c}a^{*} \\
\text { (redness) }\end{array}$ & $\begin{array}{c}\mathbf{b}^{*} \\
\text { (yellowness) }\end{array}$ & $\begin{array}{c}\mathrm{C}^{*} \\
\text { (color } \\
\text { saturation) }\end{array}$ & $\begin{array}{c}h^{*} \\
\text { (hue) }\end{array}$ \\
\hline
\end{tabular}

\begin{tabular}{|c|c|c|c|c|c|}
\hline \multirow{5}{*}{$\begin{array}{l}\text { Significant } \\
\text { effects } \\
(p<0.05)\end{array}$} & $-L$ & $\begin{array}{l}\text { - Soy extract - L } \\
(-)\end{array}$ & & & \multirow{4}{*}{$\begin{array}{l}\text { - Soy extract - L } \\
(+) \\
\text { - Guava pulp - } \\
\text { L (-) }\end{array}$} \\
\hline & & $\begin{array}{l}\text { - Guava pulp - L } \\
(+)\end{array}$ & \multirow{4}{*}{$\begin{array}{l}\text { - Soy extract - } L \\
(+)-\text { Guava pulp } \\
-L(+)\end{array}$} & \multirow{4}{*}{$\begin{array}{l}\text { - Soy extract - L } \\
(+) \\
\text { - Guava pulp - } \\
L(+)\end{array}$} & \\
\hline & $(-)$ & - Soy extract - $Q$ & & & \\
\hline & - $\quad$ Modified & & & & \\
\hline & $\begin{array}{l}\text { starch by guava } \\
\text { pulp (-) }\end{array}$ & $\begin{array}{l}-\quad \text { Modified } \\
\text { starch by guava } \\
\text { pulp }(+)\end{array}$ & & & \\
\hline
\end{tabular}

$L$ - linear effects

$Q$ - quadratic effects 
TABLE 3 - SIGNIFICANT EFFECTS ON THE SENSORY ATTRIBUTES (QDA).

\begin{tabular}{|c|c|c|c|c|c|}
\hline $\begin{array}{l}\text { Sensory } \\
\text { attributes } \\
\text { (QDA) }\end{array}$ & Soy flavor & Guava flavor & Pink color & Consistency & Creaminess \\
\hline \multirow{3}{*}{$\begin{array}{c}\text { Significant } \\
\text { effects } \\
(p<0.05)\end{array}$} & $\begin{array}{l}\text { - Soy extract - } L \\
(+)\end{array}$ & $\begin{array}{l}\text { - Soy extract - L } \\
(-)\end{array}$ & $\begin{array}{l}\text { - Soy extract - L } \\
(-)\end{array}$ & \multirow{3}{*}{$\begin{array}{ll}\text { - Soy } & \text { extract } \\
\mathrm{L}(+)- & \text { Modified } \\
\text { starch } & -\mathrm{L}(+)\end{array}$} & \multirow{3}{*}{$\begin{array}{l}\text { - Soy extract - } \\
\mathrm{L}(+)-\text { Modified } \\
\text { starch }-\mathrm{L}(+)\end{array}$} \\
\hline & $\begin{array}{l}\text { - Guava pulp - } \\
\text { L (-) }\end{array}$ & \multirow[t]{2}{*}{$\begin{array}{l}\text { - Guava pulp - L } \\
(+)\end{array}$} & \multirow[t]{2}{*}{$\begin{array}{l}\text { - Guava pulp - L } \\
(+)\end{array}$} & & \\
\hline & $\begin{array}{l}-\quad \text { Modified } \\
\text { starch - L (-) }\end{array}$ & & & & \\
\hline
\end{tabular}

(L) linear effects TABLE 4 - MEAN SCORES OF THE SAMPLES CONCERNING TO SENSORY
ATTRIBUTES RANKED IN THE AFFECTIVE TESTS.

\begin{tabular}{|c|c|c|c|c|c|c|c|}
\hline \multirow{2}{*}{ Assay } & \multicolumn{7}{|c|}{ Mean scores } \\
\hline & Appearance & Color & Consistency & Odor & Flavor & Creaminess & Acceptance \\
\hline 1 & $6.25 \pm 1.57^{\mathrm{bc}}$ & $\begin{array}{l}5.83 \pm \\
1.69^{\mathrm{ab}}\end{array}$ & $6.56 \pm 1.58^{a b}$ & $\begin{array}{l}6.02 \pm \\
1.38^{\mathrm{bc}}\end{array}$ & $\begin{array}{c}6.77 \pm \\
1.49^{a}\end{array}$ & $6.60 \pm 1.59^{b}$ & $6.48 \pm 1.34^{\mathrm{ab}}$ \\
\hline 7 & $7.06 \pm 1.42^{\mathrm{a}}$ & $6.56 \pm 1.54^{\mathrm{a}}$ & $7.40 \pm 1.45^{a}$ & $\begin{array}{l}6.65 \pm \\
1.40^{\mathrm{ab}}\end{array}$ & $\begin{array}{c}6.88 \pm \\
1.78^{a}\end{array}$ & $7.37 \pm 1.75^{\mathrm{a}}$ & $6.98 \pm 1.59^{a}$ \\
\hline 8 & $6.15 \pm 1.53^{b c}$ & $5.46 \pm 1.69^{b}$ & $7.21 \pm 1.32^{a}$ & $\begin{array}{l}6.51 \pm \\
1.45^{\mathrm{ab}}\end{array}$ & $\begin{array}{r}6.40 \pm \\
1.79^{\mathrm{ab}}\end{array}$ & $7.25 \pm 1.52^{\mathrm{a}}$ & $6.44 \pm 1.47^{\mathrm{ab}}$ \\
\hline 9 & $6.58 \pm 1.59^{a b}$ & $6.66 \pm 1.60^{a}$ & $6.22 \pm 1.71^{b}$ & $\begin{array}{c}7.10 \pm \\
1.74^{\mathrm{a}}\end{array}$ & $\begin{array}{c}6.86 \pm \\
1.58^{\mathrm{a}}\end{array}$ & $6.54 \pm 1.82^{\mathrm{b}}$ & $6.92 \pm 1.47^{a}$ \\
\hline 10 & $5.08 \pm 1.75^{d}$ & $4.46 \pm 1.83^{c}$ & $6.18 \pm 1.91^{b}$ & $\begin{array}{c}5.74 \pm \\
1.76^{c}\end{array}$ & $\begin{array}{c}5.48 \pm \\
2.01^{\mathrm{b}}\end{array}$ & $6.48 \pm 1.94^{\mathrm{b}}$ & $5.54 \pm 1.75^{c}$ \\
\hline 13 & $5.44 \pm 1.61^{c d}$ & $\begin{array}{l}4.92 \pm \\
1.72^{\mathrm{bc}}\end{array}$ & $6.70 \pm 1.49^{\mathrm{ab}}$ & $\begin{array}{l}5.88 \pm \\
1.49^{\mathrm{bc}}\end{array}$ & $\begin{array}{c}5.80 \pm \\
1.78^{b}\end{array}$ & $\begin{array}{l}6.90 \pm \\
1.57^{\mathrm{ab}}\end{array}$ & $5.68 \pm 1.80^{\mathrm{bc}}$ \\
\hline
\end{tabular}

*Means within column followed by different superscripts, are significantly different at $p<0.05$ using Tukey test.

\section{TABLE 5 - PEARSON'S CORRELATION MATRIX BETWEEN SENSORY AND INSTRUMENTAL COLOR.}

\begin{tabular}{ccccccc}
\hline Parameters & Sensory color & $\mathbf{L}^{*}$ & $\mathbf{a}^{*}$ & $\mathbf{b}^{*}$ & $\mathbf{C}^{*}$ & $\mathbf{h}_{\mathrm{ab}}$ \\
\hline Sensory color & 1.000 & -0.885 & 0.650 & -0.467 & -0.193 & -0.864 \\
$\mathbf{L}^{*}$ & -0.885 & 1.000 & -0.600 & 0.574 & 0.305 & 0.890 \\
$\mathbf{a}^{*}$ & 0.650 & -0.600 & 1.000 & 0.157 & 0.474 & -0.740 \\
$\mathbf{b}^{*}$ & -0.467 & 0.574 & 0.157 & 1.000 & 0.944 & 0.544 \\
$\mathbf{C}^{*}$ & -0.193 & 0.305 & 0.474 & 0.944 & 1.000 & 0.238 \\
$\mathbf{h}_{\mathrm{ab}}$ & -0.864 & 0.890 & -0.740 & 0.544 & 0.238 & 1.000 \\
\hline
\end{tabular}

*Marked correlations are significant at $p<0.05$

the guava pulp that presents red coloration and low lightness $\left(L^{*}=49.6 ; a^{*}=21.62 ; b^{*}=19.85 ; h_{a b}=42.57\right)$. 
As expected, different proportions of guava pulp caused significant differences on all color attributes. Negative linear effects for lightness and $h_{a b}$ were obtained, while positive linear effects were obtained for $a^{*}, b^{*}$ and $C^{*}$. The guava is a fruit rich in beta-carotene and lycopene, carotenoids compounds that have functional chromophores groups that give it yellow, red, and orange colors. The chromophore is an extensive system of conjugated double bonds and, depending on the food matrix, can be seen as different color intensities and hues (Rodriguez-Amaya, Amaya-Farfan, \& Kimura, 2007).

\subsection{ANALYSIS OF THE CORRELATION BETWEEN INSTRUMENTAL AND SENSORY DATA}

As reported above, significant differences among samples were detected both in terms of instrumental parameters for color and in terms of sensory attributes for color and texture. Similarly, the results reported in the preceding paper (Spada et al., 2014). indicated significant change in the values of the rheological parameters evaluated ( $G^{\prime}, G^{\prime \prime}, n^{\prime}, n^{\prime \prime}, K, h 10$ and $Q$ ) as a function of the composition of these samples. So, possible correlations between these data were explored by using correlation matrices (Pearson correlation coefficient).

Table 5 shows the results of the Pearson's correlation matrix between the sensory color and instrumental color parameters. No significant correlations were found between sensory color data and $b^{*}$ or $C^{*}$ parameters $(r=-0.46$ and -0.19 , respectively). Results showed a moderate positive correlation between sensory pink color and parameter $a^{*}(r=0.65)$, and high negative correlations with parameters $L^{*}$ and $h_{a b}\left(r=-0.88\right.$ and -0.86 , respectively). The parameter $h_{a b}$ was identified as a good indicator of sensory color because it characterizes the quality of color from red to yellow (higher hue angle represents a greater yellow character in the assays and a lesser redness intensity) and these colors are predominant in the samples. Respect the relationship between sensory pink color and $L^{*}$, as mentioned above, the pulp addition promotes a decrease in $L^{*}$ values, since it is capable of causing browning of the samples, and these differences were perceived by panel. Tárrega and Costell (2007) studied the correlation between sensory color and color parameters of vanilla custard desserts and found similar results, finding a significant positive correlation between sensory color and $a^{*}$, significant negative correlations with $L^{*}$ and $h_{a b}$ and no significant correlations between sensory color data and $b^{*}$ or $C^{*}$.

Table 6 shows the results of the Pearson's correlation coefficients $(r)$ between sensory and rheological parameters. Consistency and creaminess showed a good correlation with both the flow ( $k, n$ and $h_{10}$ ) and viscoelastic rheological parameters ( $G^{\prime}, G^{\prime \prime}, n^{\prime}$ and $\left.n^{\prime \prime}\right)$. The viscoelastic parameter $G$ " at 1 and 10 rad s$^{-1}$ presented the highest correlation coefficients with the sensory attributes; this way, $G$ " at 10 rad s$^{-1}$ was the chosen parameter to compare the samples. Sample 9, which was significantly different of others due to its lower consistency and creaminess, presented $G_{10}$ " value of $70 \mathrm{~Pa}$. In contrast, samples $4,7,8,10$ and 12, considered as more consistent and creamier by the trained panel, presented $G_{10}$ " values in the range of $157-204 \mathrm{~Pa}$. With regard to the other samples of experimental design, the values of $G_{10}$ " ranged between 88 and $144 \mathrm{~Pa}$. Despite these samples presented large range of rheological values, they presented similar ranking sensory, i.e, the trained panel presented more difficult to differentiate them. This indicates that some differences in the composition of the samples did not implicate in how much consistency and creaminess was perceived by individuals. Therefore, from a practical viewpoint, some selected rheological parameters can be used as instrumental index to identify texture changes detectable by consumers in this type of products. 
TABLE 6 - PEARSON CORRELATION COEFFICIENT BETWEEN SENSORY AND RHEOLOGICAL PARAMETERS.

\begin{tabular}{ccc}
\hline \multirow{2}{*}{ Rheological parameters } & \multicolumn{2}{c}{ Sensory attributes } \\
\cline { 2 - 3 } & Consistency & Creaminess \\
\hline$G_{1}^{\prime}$ & 0.768 & 0.721 \\
$G^{\prime \prime}{ }_{1}$ & 0.876 & 0.815 \\
$G^{\prime}{ }_{10}$ & 0.828 & 0.778 \\
$G^{\prime \prime}$ & 0.879 & 0.814 \\
$n^{\prime}$ & -0.803 & -0.770 \\
$n^{\prime \prime}$ & -0.847 & -0.817 \\
$K$ & 0.802 & 0.753 \\
$n$ & -0.750 & -0.748 \\
$\eta_{\mathrm{ap}}$ & 0.797 & 0.737 \\
$\eta^{*}{ }_{50}$ & 0.858 & 0.799 \\
\hline
\end{tabular}

\section{CONCLUSION}

The objective of this work was achieved, since that the variations perceived by the consumers in color and texture of creamy soy based desserts showed important relationships with instrumental measurements. The color of the samples verified by QDA can be well correlated with the color parameters measured with a colorimeter. The lightness $\left(L^{*}\right)$ and tonality $\left(h_{a b}\right)$ presented higher Pearson's correlation coefficient with the pink color perceived. Moreover, many rheological properties were highly correlated with the sensory properties regarding to resistance to flow out of the spoon (consistency) and perception of soft consistency in the mouth (creaminess). In addition, the data verified in the affective tests were explained by the results verified in the QDA. Therefore, the results obtained in this work provide information of practical use in the industrial food product process monitoring and development.

\section{RESUMO}

\section{PROPRIEDADES SENSORIAIS DE SOBREMESAS CREMOSAS À BASE DE SOJA PREDITAS POR MEDIDAS INSTRUMENTAIS RÁPIDAS}

O objetivo deste trabalho foi entender o quanto as propriedades reológicas podem explicar a textura sensorial de sobremesas à base de soja contendo diferentes quantidades de extrato hidrossolúvel de soja, amido modificado e polpa de goiaba; bem como correlacionar a cor avaliada por painel sensorial com a medida instrumental. Para tanto, dezessete sobremesas cremosas foram estudadas. Testes sensoriais foram feitos através da Análise Descritiva Quantitativa (ADQ) e por testes afetivos. As correlações entre dados instrumentais e sensoriais foram determinadas pelo coeficiente de correlação de Pearson. Os resultados mostraram uma moderada correlação positiva entre a cor sensorial e o parâmetro $a^{*}$, e correlações significativas e negativas com $L^{*}$ e $h_{a b}$. Os módulos de perda a 1 e 10 rad s$^{-1}$ e o parâmetro $n$ " foram os dados reológicos que melhor se correlacionaram com os atributos sensoriais relacionados à consistência e cremosidade das amostras. Além disso, os resultados encontrados nos testes afetivos foram explicados pelos verificados na ADQ.

PALAVRAS-CHAVE: ADQ, REOLOGIA, COR, ALIMENTOS COM SOJA. 


\section{REFERENCES}

1 ARLTOFT, D.; MADSEN, F.; IPSEN, R. Relating the microstructure of pectin and carrageenan in dairy desserts to rheological and sensory characteristics. Food Hydrocolloids, v.22, n.4, p.660-673, 2008.

2 DE WIJK, R. A.; PRINZ, J. F.;JANSSEN, A. M. Explaining perceived oral texture of starch-based custard desserts from standard and novel instrumental tests. Food Hydrocolloids, v.20, n1, p.24-34, 2006.

3 DE WIJK, R. A.; VAN GEMERT, L. J.; TERPSTRA, M. E. J.; WILKINSON, C. L. Texture of semi-solids; sensory and instrumental measurements on vanilla custard desserts. Food Quality and Preference, v.14, n.4, p.305-317, 2003.

4 DEPYPERE, F. D. R.; VERBEKEN, D.; THAS, O.;DEWETTINCK, K. Mixture design approach on the dynamic rheological and uniaxial compression behaviour of milk desserts. Food Hydrocolloids, v.17, n.3, p.311-320, 2003.

5 DIJKSTERHUIS, G. Multivariate data analysis in sensory and consumer science. Food and Nutrition Press, 1997.

6 LETHUAUT, L.; BROSSARD, C.; ROUSSEAU, F.; BOUSSEAU, B.;GENOT, C. Sweetness - texture interactions in model dairy desserts: effect of sucrose concentration and the carrageenan type. International Dairy Journal, v.13,n.8, 631-64, 2003.

7 RODRIGUEZ-AMAYA, D. B. A.; AMAYA-FARFAN, J.; KIMURA, M. Carotenoid composition of Brazilian fruits and vegetables. Acta Horticulturae, v.744, p.409-416, 2007.

8 SPADA, J. C.; DICK, M.; PAGNO, C. H.; VIEIRA, A. C.; BERNSTEIN, A.; COGHETTO, C. C.; MARCZAK, L. D. F.; TESSARO, I. C.; CARDOZO, N. S. M.; FLÔRES, S. H. Physical, chemical and sensory characterization of soy-based desserts made with chia mucilage. Ciência Rural, v.44, n.2, p.374-379, 2014.

9 SPADA, J. C., MARCZAK, L. D. F., TESSARO, I. C., FLÔRES, S. H., \& CARDOZO, N. S. M. Rheological modelling, microstructure and physical stability of custard-like soy-based desserts enriched with guava pulp. CyTA - Journal of Food, http://dx.doi.org/10.1080/19476337.2014.987698, 2014.

10 TÁRREGA, A., \& COSTELL, E. (2007). Colour and consistency of semi-solid dairy desserts: Instrumental and sensory measurements. Journal of Food Engineering, v.78, n.2, p.655-661, 2007.

11 WENDIN, K., \& HALL, G. Influences of Fat, Thickener and Emulsifier Contents on Salad Dressing: Static and Dynamic Sensory and Rheological Analyses. Lebensmittel-Wissenschaft und-Technologie, v.34, n.4, p.222-233, 2001.

12 WORTEL, V. A. L.; VERBOOM, C.; WIECHIERS, J. W.; TAELMAN, M.; LEONARD, S. (2005). Liking sensory and rheological characteristics. Cosmetics \& Toiletries, v.120, n.4, p.57-66, 2005.

\section{ACKNOWLEDGEMENTS}

The authors acknowledge the financial support received from CNPq (Conselho Nacional de Desenvolvimento Científico e Tecnológico). 